\title{
INTRODUÇÃO DE CONCEITOS ESTATÍSTICOS REALIZANDO ANÁLISES DE REDES SOCIAIS NUMA ESCOLA BILÍNGUE
}

\author{
Adriana Pimenta ${ }^{1}$, Bruno Neto ${ }^{2}$, Letícia $\mathrm{Cruz}^{2}$, Ana Buçard ${ }^{2}$. \\ ${ }^{1}$ Docente do Departamento de Matemática e Estatística e ${ }^{2}$ Discentes da Escola de Matemática \\ Universidade Federal do Estado do Rio de Janeiro - UNIRIO - Brasil \\ adriana.pimenta@uniriotec.br
}

Trilhando caminhos da realidade de uma sociedade virtual, muito presente na geração de estudantes do ensino fundamental, buscamos desenvolver atividades que envolvem os conteúdos de medidas de tendência central atrelado ao uso das redes sociais. Uma vez que o trabalho foi realizado numa escola bilíngue, este foi direcionado a fim de determinar as diferenças associadas à aprendizagem de conteúdos de estatística, quando esta é abordada em português e em inglês.

Esta proposta foi dividida entre o quinto e o sétimo ano do Ensino Fundamental. Para o desenvolvimento do estudo no quinto ano, foram selecionadas duas turmas, sendo uma com 23 alunos cuja atividade foi desenvolvida em português e a outra com 12 alunos, que ocorreu em inglês. O trabalho visa ler e interpretar gráficos e tabelas, para a abordagem dos conceitos de moda e média. No sétimo ano a proposta foi desenvolvida com uma turma de 12 alunos e com o objetivo de tratar os conceitos de moda, média, mediana e uma pequena introdução de grafos.

No quinto ano aplicamos uma atividade, cujo objetivo era introduzir os tópicos de média, moda e mediana. Para isso usamos coleta de dados. A atividade foi realizada da seguinte forma: os dados foram coletados pedindo para que os alunos colocassem em cima de suas mesas seus lápis favorito, em seguida medindo o tamanho de cada lápis e essas medidas foram anotadas no quadro. Após ser feita a coleta de dados, introduzimos o conceito de gráfico a partir das informações contidas em uma tabela de frequência relacionando o tamanho do lápis e a quantidade de alunos que possuíam um lápis de determinado tamanho. O gráfico foi desenhado e iniciou-se a parte principal do trabalho que consistia da introdução dos conceitos de tendência central. Os alunos não demonstraram dificuldade em compreender o conceito de média, e moda (pelo fato de ser feita a associação com o termo: "o que esta na moda"). Quando introduzido o conceito de mediana também não foi notada dificuldade, uma vez que o gráfico possibilitou uma visão diferenciada. Como essa atividade foi aplicada em duas turmas, em uma a aula ocorreu em inglês e outra em português e em ambas foi constatada boa compreensão por parte dos alunos das medidas de tendência central. Como uma das turmas era menor, julgamos não ser benéfico trabalhar a tabela de frequência devido a um baixo conjunto amostral.

No sétimo ano como os alunos já haviam tido contato com o tópico: tendência central, em português. A abordagem nessa turma foi feita em inglês. Nosso objetivo era verificar se eles sabiam os conceitos em inglês e se sabiam interpretar gráficos. Logo usamos o tópico de rede social para fazer a introdução do conceito em inglês. Perguntas sobre quantas redes sociais eles usavam, se eles tinham facebook, há quanto tempo eles usavam, quantas horas por dia estavam conectados, entre outras que foram feitas com intuído de se criar um espaço amostral para trabalhar os conceitos estatísticos. Por fim, foi entregue uma lista com 5 exercícios: três apenas com os conceitos básico, uma de interpretação de gráficos e a última utilizando o exemplo do Instagram e do Twitter (seguir e ser seguido) onde os alunos pudessem determinar qual seria o usuário mais popular, vislumbrando o conceito de moda que para sua resolução desenhou-se um diagrama, um grafo ordenado, o que permitiu uma melhor visualização dos alunos, o que ocorreu de forma fluída.

\section{REFERENCES}

1. Ministério da educação (1998). Parâmetros Curriculares Nacional: Ensino Fundamental ( $5^{\circ}$ a $8^{\circ}$ series): Matemática. Secretaria de Ensino Fundamental. Brasília: MEC/sef.

2. LANGE, Catherine de. Bilíngues tem vantagens no aprendizado.

$$
\underline{\text { http://revistagalileu.globo.com/Revista/Common/0,EMI313503-17579,00- }}
$$

In: M.A. Sorto (Ed.), Advances in statistics education: developments, experiences and assessments. Proceedings of the Satellite conference of the International Association for Statistical Education (IASE), July 2015, Rio de Janeiro, Brazil. 